\title{
Membangun Daya Saing Institusi Pendidikan Berbasis Kompetensi Dasar Organisasi
}

\author{
Edy Suandi Hamid \\ Universitas Islam Indonesia
}

\begin{abstract}
This article is intended to discuss some experiences of the Islamic University of Indonesia (Universitas Islam Indonesia, hereinafter UII) in developing its core competences as the main source of competitiveness to face higher education changes and challenges. This article reveals that the UII has developed its core competences mainly in the arts of management and govemance of the university. The UII has introduced a more simple but flexible structure of management in all units, in order to reduce cost and to fasten decision making process. Using such a management and governance, the UII has developed its main activities based on its mission to promote Islamic values, as blessing for all creatures. This article suggests that universities, especially those of Islamic ones, develop their core competences based on management and govemance issues, such as the real world challenges, commitments, and Islamic values.
\end{abstract}

\section{Keywords: Core competences, competitiveness, management, governance}

\begin{abstract}
A
bad ke-21 yang ditandai dengan perkembangan pesat di bidang Teknologi Informasi dan Komunikasi (TIK) telah membawa banyak perubahan dalam berbagai institusi dan struktur kehidupan manusia, tidak terkecuali dunia pendidikan dan berbagai institusi di dalamnya. Persaingan sebagai ciri utama peradaban modern telah berkembang melewati banyak batas dunia seiring makin mantapnya penguasaan TIK. Tingkat persaingan yang muncul kemudian berkembang sedemikian pesat dan tidak lagi terbatas pada batas negara. Dalam artian seluruh entitas dunia pada dasamya hidup dalam persaingan yang tinggi seiring capaian dan penggunaan TIK.

Dunia pendidikan pun mautidakmau ikut terlibat dalam persaingan ini. Berbagai model pembelajaran yang diberikan institusi pendidikan dari beragam tingkatan sudah barang tentu menjadi pilihan masyarakat,
\end{abstract}

sesuai dengan kebutuhan dan kemampuan untuk mencapainya. Mengingat masyarakat merupakan subjek pendidikan yang aktif dan partisipatif dalam memberikan penilaian, institusi pendidikan pun dituntut untuk menunjukkan profesionalitas dalam pemberian layanan kepada masyarakat, demi menjamin kesinambungan pilihan masyarakat terhadap model pembelajaran yang diberikan institusi pendidikan tersebut. Persaingan di dunia pendidikan kemudian berkembang ke arah yang lebih jauh, seiring dampak langsung globalisasi ke berbagai penjuru dunia. Masuknya pendidikan dalam kerangka GATS (General Agreement on Trades and Services) secara langsung membuka kran persaingan di dunia pendidikan dengan melibatkan lebih banyakpemain.

Tingginya tingkat persaingan di dunia pendidikan ini menyebabkan institusi pendidikan harus bersiap diri, melakukan 
transformasi organisasi, untuk mencari keunggulan yang bisa menjamin terjaganya eksistensi institusi pendidikan dalam persaingan yang makin ketat. Makalah ini dimaksudkan untuk melihat bagaimana kompetensi dasar organisasi bagi pendidikan tinggi dikembangkan dalam rangka meningkatkan daya saing dalam menghadapi kompetisi global di dunia pendidikan. Mengingat kajian ini sangat dekat sifatnya dengan studi ilmu ekonomi dan manajemen, maka beberapa pendekatan di dua bidang tersebut akan banyak digunakan. Ditambah beberapa pengalaman institusi pendidikan di negara lain yang lebih dahulu merasakan iklim kompetitif dalam bidang pendidikan. Beberapa istilah dan penjelasan teknis akan dibahas untuk mempertegas berbagai persepsi yang diadopsi dari kajian-kajian ilmu ekonomi dan menajemen, untuk kemudian dianalisis dalam konteks pendidikan, ditambah dengan penerapannya bagi pendidikan di Indonesia, dengan mengambil pengalaman UII sebagai bagian pembahasan.

\section{Daya Saing bagi Institusi Pendidikan}

Wikipedia online (2007) mengartikan daya saing (competitiveness) sebagai a comparative concept of the ability and performance of a firm, sub-sector or country to sell and supply goods and/or services in a given market. Dengan demikian dalam kerangka ini, daya saing memiliki tingkat komparasi antara satu entitas yang ikut dalam sebuah kompetisi dengan entitas lainnya. Lebih jauh Wikipedia juga menjelaskan bahwa competitiveness, seringkali dipakai dalam kerangka pasar yang strukturnya persaingan sempurna (perfect competition). Hal ini menunjukkan bahwa sebuah perusahaan dikatakan memiliki daya saing manakala, mampu bersaing dengan pemain dalam pasar yang relatif sama, dimana masing-masing pelaku dalam pasar tidak memiliki kekuatan monopoli.

Dalam kerangka ekonomi dan manajemen, konsep daya saing memiliki peran yang sangat penting dalam menjaga sustainability perusahaan dalam memenangkan persaingan bisnis. Munculnya daya saing sebuah perusahaan (competitiveness of firms) bagi Porter (1990), dalam Chou dan Chang (2004) merupakan implikasi yang muncul dari kebutuhan akan kemampuan berkompetisi di pasar internasional melalui berbagai strategi untuk memenangi globalisasi. Meskipun demikian, dalam kerangka Porter untuk melihat tingkat daya saing, tidak harus dilakukan melalui analisis komparatif yang kaku yang biasa digunakan. Sebagai contoh dalam bisnis 'pembangunan kapal laut', biaya per unit output sudah mencukupi untuk melihat efektivitas pembangunan sekaligus menjadi ukuran daya saing (Storck,et.al,1995) dan Chang (2004).

Jika dibawa dalam konteks pendidikan tinggi, maka pada dasarnya terdapat tiga proses inti proses pendidikan (core process), yaitu pengajaran (teaching), penelitian (research), dan pelayanan (services) (Indrajit dan Djokopranoto, 2006). Ini berarti bahwa dalam pengelolaan ketiga core process, perguruan tinggi dituntut memiliki keunggulan sehingga tercipta daya saing yang memadai. Keunggulan sebagai bentuk daya saing ini, antara lain terlihat dari kemampuan perguruan tinggi merespon perubahan global, sebagai konsekuensi adanya persaingan di dunia pendidikan.

\section{Kompetensi Dasar dalam Institusi Pendidikan}

Ulrich dan Lake dalam Chou (Storck, et.al,1995) dan Chang (2004) mengajukan 
arti kemampuan organisasi (organizational capability) sebagai kemampuan untuk membangun struktur internal dan proses dalam sebuah perusahaan dan struktur serta proses ini dapat mempengaruhi pekerja untuk menciptakan kapasitas organisasi yang memadai. Dengan demikian, sebuah organisasi dikatakan memiliki kemampuan organsiasi yang baik manakala organisasi tersebut mampu menyesuasikan diri dengan berbagai persyaratan strategis dan perubahan lingkungan bisnis.

Penelitian strategis yang menjadi trend pada tahun 1980-an dan awal 1990-an menunjukkan bahwa sangat mungkin bagi perusahaan untuk mencapai dan mempertahankan keuntungan kompetitif (competitive advantage), sebuah posisi unik dibandingkan perusahaan lain yang memungkinkan sebuah perusahaan secara konsisten unggul dalam persaingan dengan perusahaan lainnya (Porter, 1985 dalam Chou dan Chang, 2004). Penelitianpenelitian mengenai keunggulan kompetitif yang dilakukan setelah Porter, banyak difokuskan pada kompetensi dasar (core competence) sebagai sumber keunggulan (Foil, 2001 dalam Chou (Storck,et.al, 1995) dan Chang (2004).

Kompetensi dasar sendiri diartikan dengan beragam makna, antara lain sebagai kemampuan belajar secara kolektif dalam sebuah organisasi, khususnya bagaimana mengkoordinasikan kemampuan produksi yang berbeda-beda, dan mengintegrasikan beragam model teknologi (Prahalad dan Hamel, 1990 dan Wright, Dunford, dan Snell, 2001 dalam Chou dan Chang, 2004). Collis (1991 dalam Chou dan Chang, 2004) mendefinisikan kompetensi dasar perusahaan sebagai sekumpulan aset yang membuat sebuah perusahaan unggul dengan keunikan tertentu dan aset ini berasal dari kemampuan teknologi yang beragam, aset pelengkap, rutinitas dan kapasitas organisasi. Sedangkan Javidan (1998 dalam Chou dan Chang, 2004) mengartikan kompetensi dasar sebagai kemampuan dan wilayah pengetahuan yang dibagikan kepada seluruh unit bisnis dan dihasilkan dari integrasi dan harmonisasi kompetensi setiap unit bisnis.

Dalam konteks institusi pendidikan, core competence organisasi juga menjadi bagian penting dalam penyelenggaraan pendidikan tinggi. Bentuk dari core competence sendiri bisa jadi sangat beragam dari satu institusi dengan institusi lainnya. Sebagai contoh beberapa perguruan tinggi di Indonesia, memiliki core competence pada aplikasi TIK, pengeloiaan dan penjaminan mutu, program studi unggulan, fakultas unggulan, dan lain sebagainya. Core competence pada beragam aspek ini selanjutnya menjadi semacam endorser, yang menjadikan nama baik perguruan tinggi terbentuk di masyarakat, sehingga mampu memback-up trend penurunan mahasiswa pada perguruan tinggi bersangkutan. Dalam kasus tertentu bahkan, core competence yang dimiliki PTS bisa jadi melebihi PTN pada bidang yang spesifik. Ini menandakan terjadinya penyebaran berbagai core competence yang menjadi ciri khusus bagi perguruan tinggi.

Lalu bagaimana, perguruan tinggi mampu membentuk core competence yang dapat diandalkan dalam persaingan global seperti saat ini? Kembali akan kita lihat konsep ekonomi dan manajemen untuk menjelaskan permasalahan ini. Pada dasarnya perusahaan memiliki banyak sumber daya yang bisa dijadikan dasar pembentukan kompetensi dasar, serta untukmencapai dan mengimplementasikan strategi penciptaan nilai. Barney (1991, dalam Chou dan Chang, 2004) misalnya menyebutkan bahwa sumber daya peru- 
sahaan yang dapat digunakan meliputi tiga modal pokok, yaitu: sumberdaya fisik, sumberdaya manusia, dan sumberdaya organisasi. Chatterjee dan Wernerfeld (1991) merekomendasikan tiga sumber daya perusahaan, yaitu: sumberdaya fisik, aset tak terlihat, dan sumber daya keuangan. Sedangkan Fernandez, Montes dan Vazquez (2000) mempertegas bahwa sumberdaya tak terlihat (intangible resources) dapat diklasifikasikan dalam modal manusia, modal organisasi, modal relasional, dan modal teknologi.

Lebih jauh Prahalad dan Hamel (1990, dalam Holmes dan Hooper, 2000) menyebutkan bahwa kekuatan kompetitif dalam sebuah bisnis akan terjadi manakala terdapat sesuatu yang unik, relevan, dan memiliki potensi tawaryang tinggi. Terdapat empat kriteria yang harus dipenuhi agar kapasitas perusahaan benar-benar menjadi core competence, yaitu: (1) dianggap bernilai oleh konsumen; (2) relevan pada berbagai kondisi pasar; (3) harus berdasar pada kemampuan keilmuan, dan; (4) sebaiknya tidak bersifat fisik yang memungkinkan terjadinya duplikasi oleh pesaing.

Melihat paparan di atas, maka beberapa poin penting dapat dijadikan bahan pertimbangan dalam membangun core competenceperguruan tinggi. Hampir sama seperti perusahaan, perguruan tinggi juga dilengkapi (meskipun dengan berbagai keterbatasan) dengan berbagai sumberdaya, mulai dari sumberdaya fisik, berupa fasilitas pendidikan, aset perguruan tinggi, dll; sumberdaya manusia, berupa staf akademik dan staf administrasi; sumber daya organisasi, berupa struktur dan tata kelola yang selama ini telah ber.jalan dalam menjalankan organisasi perguruan tinggi; dan hubungan kerjasama dengan berbagai stakeholders yang tentu saja ikut menentukan perjalanan perguruan tinggi. Ini berarti secara konseptual berbagai sarana dan prasarana yang dibutuhkan perguruan tinggi, dan juga institusi pendidikan lainnya dalam menghasilkan core competence bagi peningkatan daya saing (competitiveness) secara umum sudah terpenuhi. Tinggal kini bagaimana organisasi perguruan tinggi menggerakkan dan mengarahkan sumber daya yang ada untuk mencapai daya saing yang optimal.

\section{Membangun Daya Saing Institusi Pendidikan Berbasis Kompetensi Dasar Organisasi}

Membangun daya saing dengan mengandalkan kompetensi dasar organisasi pada dasarnya merupakan upaya realistis yang diambil sebuah institusi pendidikan dalam menghadapi persaingan di dunia pendidikan. Hampir dipastikan akan sulit bagi sebuah institusi pendidikan untuk unggul di segala bidang, mengingat tidak ada satu pun institusi pendidikan yang menjadi pemain tunggal, atau yang dalam kerangka ilmu ekonomi biasa disebut monopoli. Semua institusi pendidikan sebagai pelaku dalam pasar pendidikan, mau tidak mau harus memilih salah satu aspek sebagai core competence yang kemudian diangkat menjadi entry point utama dalam membentuk daya saing institusinya.

Dalam konteks Indonesia, secara pragmatis daya saing institusi pendidikan, secara lebih khusus pendidikan tinggi, sering kali dilihat dari kinerja alumninya. Kinerja alumni ini tidak saja dilihat dari bagaimana karier dan pengabdian alumni di masyarakat, melainkan juga seberapa cepat masa tunggu mereka untuk mendapatkan pekerjaan atau bahkan menciptakan lapangan kerja baru. Oleh karena itu, tuntutan konsumen, dalam hal ini perusahaan dan dunia industri maupun 
masyarakat umum, harus pula menjadi pertimbangan pengelola pendidikan tinggi dalam mendesain kurikulum dan proses pendidikannya. Desain kurikulum yang kompetitif tentu saja tidak hanya terkait dengan hard skill, tetapi juga soft skillyang penting dalam pengembangan karier.

Selain itu kontribusi penelitian (research) sebagai upaya memperoleh dukungan pihak ketiga juga penting untuk diperhatikan dalam rangka meningkatkan daya saing. Dukungan pendanaan yang diperoleh melalui pihak ketiga, baik perusahaan, pemerintah, ataupun pihak terkait lainnya, dalam kerangka penelitian dan pengembangan selain akan membantu kemampuan finansial institusi pendidikan, juga akan meningkatkan posisi tawar institusi dalam percaturan intelektual di berbagai bidang. Dengan jumlah mitra yang semakin meningkat, peluang raihan pendanaan yang besar tentu saja makin terbuka bagi berbagai institusi pendidikan. Dengan demikian pengelola institusi pendidikan, secara bertahap tidak akan terlalu tergantung pada sumbangan mahasiswa dalam rangka pelaksanaan operasional tugasnya.

Sebagai contoh Universitas Gadjah Mada dapat dilihat sebagai salah satu universitas dengan reputasi pendidikan tinggi di Indonesia yang mampu membangun core competence pada beberapa bidang keilmuan sehingga pada November 2007 mampu berada pada peringkat 360 dunia menurut THES-QS Wordd University Rankings 2007. Selain itu UGM juga masuk ke-57 perguruan tinggi terbaik Asia menurut peringkat Webometrics. Capaian UGM ini mengindikasikan bagaimana sebuah strategi kompetisi berbasis kompetensi dasar bisa digali dan ditumbuhkan sehingga menjadi kekuatan yang melahirkan daya saing yang dikaui bahkan di tingkat internasional.
Memperhatikan capaian UGM tersebut, dapat dirumuskan beberapa strategi penting dalam upaya membangun kompetensi dasar organisasi sebagai modal mencapai daya saing. Langkah pertama, adalah identifikasi karakteristik yang menjadi kompetensi dasar institusi pendidikan. Selanjutnya, kompetensi dasar ini dikembangkan dengan meningkatkan kapasitas organisasi yang memungkinkan pengembangan keunggulan bisa berlangsung dalam suasana yang kondusif. Langkah selanjutnya adalah peningkatan kapasitas keunggulan pada kompetensi dasar melalui evaluasi yang terencana, terukur, dan teratur secara periodikal demi menjaga konsistensi keunǵgulan. Hasil evaluasi inj selanjutnya dijadikan bahan utama pengembangan lebih lanjut kompetensi dasar organisasi, termasuk kemungkinan pengembangannya pada aspek dan karakteristik lain dalam institusi pendidikan.

\section{Pengalaman UII dalam Membangun Daya Saing}

Pengalaman Universitas Islam Indonesia (UII) dalam upaya membangun daya saing dapat dilihat dari komitmen pimpinan dan pengelola untuk menjamin pelaksanaan pendidikan tinggi yang berkualitas. $\mathrm{Hal}$ ini antara lain dilakukan dengan pemgauatan beberapa kompetensi dasar dalam manajemen dan organisasi, yang antara lain diwujudkan pada 1) pendirian Badan Penjaminan Mutu, 2) pendirian Program Internasional, 3) penguatan IT sebagai basis pelayanan kepada mahasiswa, orang tua, dan alumni, serta 4) optimalisasi networking salah satunya dengan penguatan jaringan alumni, yang menyebar di berbagai wilayah di dalam dan luar negeri. Badan Penjaminan Mutu UII didirikan pada tanggal 1 Maret 1999 dengan nama Badan Kendali 
Mutu dan Pengembangan Pendidikan (BKMPP). BKMPP mempunyai tugas utama untuk pembuatan, penerapan dan pengembangan Sistem Manajemen Mutu serta pengembangan konsep-konsep dan disain pendidikan di UII.

Dalam perkembangannya, BKMPP sejak tanggal 20 September 2003 dipisah menjadi.2 (dua) badan yaitu Badan Kendali Mutu dan Badan Pengembangan Akademik. Sejak 2006 UII melaksanakan restrukturisasi keorganisasian, dan untuk unit penjaminan mutu yang sebelumnya Badan Kendali Mutu berubah menjadi Badan Penjaminan Mutu (BPM). BPM adalah badan yang bertanggung jawab terhadap pembangunan, pelaksanaan dan pengembangan Sistem Manajemen Mutu/Sistem Penjaminan Mutu di lingkungan UII, berkedudukan di universitas dan mempunyai perwakilan di tingkat Fakultas yang disebut dengan Pengendali Sistem Mutu Fakultas (PSMF) serta bertanggungjawab kepada Rektor. BPM dan perangkatnya merupakan wakil dari manajemen dalam hal yang berkaitan dengan Sistem Manajemen Mutu.

Langkah kedua dalam kerangka penguatan daya saing dilakukan UII dengan membuka program internasional. Pembukaan program internasional ini dimulai dengan Fakultas Ekonomi ( $F E$ ) yang melakukan kerjasama dengan Wollonggong University Australia pada tahun akademik 1996/1997. Tiga Program studi di FE UIl, yaitu masing-masing Manajemen, Akuntansi, Ilmu Ekonomi Studi Pembangunan (sekarang llmu Ekonomi) memberi peluang bagi setiap mahasiswa yang menempuh studi di IP untuk meraih pendidikan ganda, yaitu di IP FE UII dan dilanjutkan di Wollonggong University. Dengan demikian mahasiswa dapat memperoleh dua ijazah, yaitu dari dalam dan luar negeri. Selain mengirimkan mahasiswa ke luar negeri, IP FE UII juga menerima mahasiswa asing yang akan mengambil beberapa mata kuliah pada semester tertentu. Beberapa universitas luar negeri yang mahasiswanya mengambil pelajaran di IP antara lain adalah Australia National University, Deakin University, University of Sidney dan Murdoch University (Australia). IP selanjutnya berkembang pada dua fakultas lainnya, yaitu Fakultas Hukum, yaitu prodi Ilmu Hukum dan Fakultas Teknologi Industri, yaitu pada prodi Teknik Industri.

Langkah ketiga berupa peningkatan teknologi informasi sebagai instrumen pendidikan yang sejak tahun' 1982 telah mulai diterapkan dengan dibentuknya Pusat Komputer. Salah satu program awalnya adalah pemanfaatan perangkat komputer untuk pengolahan data penerimaan mahasiswa baru. Selanjutnya pemanfaatan komputer berkembang untuk mengolah data keuangan dan data akademik yang digunakan secara sendiri-sendiri (stand alone). Jaringan komputer lokal (Local Area Network) mulai dimanfaatkan tahun 90-an, diawali oleh Pusat Komputer kemudian diikuti oleh fakultas di lingkungan UII, terutama bagian akademik dan perpustakaan. Tahun 1996/1997 disusun sebuah Rencana Induk Pengembangan (RIP) Sistem Informasi Manajemen Perguruan Tinggi (SIMPT) dan Jaringan Komputer dan Komunikasi (JKK) di Ull. RIP ini berisi rencana pengembangan aplikasi-aplikasi sistem informasi manajemen (SIM) yang terintegrasi untuk perguruan tinggi dengan aplikasi-aplikasi.

Pada perkembangannya, Pusat Komputer ini kemudian berganti nama dan diperluas wewenangnya hingga saat ini menjadi Badan Sistem Informasi (BSI) yang langsung bertanggung jawab kepada Rektor. 
Visi BSI adalah menjadi penyedia handal sistem informasi/teknologi informasi yang bermanfaat dan bernilai strategik kepada semua stakeholders selaras dengan visi universitas. Misi BSI adalah (1) menyediakan produk dan layanan sistem informasi/ teknologi informasi yang bernilai tambah kepada end-user yaitu mahasiswa, dosen dan karyawan, (2) memberikan kontribusi terhadap nilai bisnis universitas, (3) menyediakan produk dan layanan sistem informasi/teknologi informasi secara efisien dan efektif, (4) melakukan perbaikan yang berkelanjutan dan mempersiapkan diri untuk menghadapi tantangan teknologi dan proses bisnis masa depan.

Dari aspek infrastruktur, sistem informasi di Ull dirancang berbasis 3-tier architecture yang mengedepankan keamanan sistem jaringan. Dengan sistem ini, maka terdapat pemisahan antara serverserver yang berhubungan langsung dengan klien dan end-user dengan pangkalan data lewat perantara middle tier server (MTS). Infrastruktur jaringan komunikasi internal di UII yang terdiri dari beberapa kampus di lingkungan DIY dihubungkan dengan menggunakan jaringan komunikasi radio (wireless networking) sebagai Metropolitan Area Network (MAN) UII yang sudah terinstalasi sejak tahun 1997. Di Kampus Terpadu terpasang fiber optic yang menghubungkan server dengan seluruh gedung utama dan fakultas sedangkan di seluruh gedung fakultas terdapat jaringan internal yang melayani pengguna secara langsung baik dalam bentuk jaringan kabel maupun nirkabel (WIFI).

Hingga saat ini, total kapasitas internet yang dipakai UII adalah 3 Mbps hingga 5 Mbps untuk mengantisipasi program kelas e-Learning terpadu (www.klasiber.uii.ac.id) yang dikembangkan mulai tahun 2007, disamping e-Learning spesifik seperti pro- gram studi Informatika yang memperoleh Program Hibah Kompetisi (PHK) A-2 dan program studi Arsitektur melalui PHK A-3, yang telah ada sebelumnya. Selain untuk kepentingan manajemen, terdapat juga fasilitas untuk kepentingan mahasiswa dalam bentuk warung internet (warnet), hotspot zone, anjungan-anjungan komputer mandiri untuk akses internet dan pelayanan berbasis sistem informasi berupa fasilitas anjungan komputer di setiap fakultas untuk kepentingan pengisian rencana studi online mahasiswa. Pengembangan selanjutnya diarahkan pada pembuatan warnet-warnet untuk mahasiswa di beberapa gedung utama.

Sebagai media otomasi pelayanan, saat ini terdapat 9 aplikasi berbasis intranet dan 10 aplikasi sistem informasi berbasis internet. Di antaranya yang utama adalah Sistem Informasi Akademik, Inventaris, Keuangan dan Bank, dan Sumber Daya Manusia. Sementara untuk layanan internet, UII memiliki Layanan Informasi Akademik bagi mahasiswa serta orang tua atau wali yang memungkinkan mereka mengetahui perkembangan studi putranya. Pada proses pendaftaran mahasiswa baru juga sudah memanfaatkan komputer sejak proses bayar, key-in data calon, kemudian untuk tes peserta dapat memilih akan dapat memilih dengan sistem Paper Based Test (PBT) atau Computer Based Test (CBT). Adapun kelebihan CBT adalah seorang calon mahasiswa baru dapat melakukan proses pendaftaran mahasiswa baru hanya dalam waktu yang relatif singkat atau sering disebut dengan istilah One Stop Services, yaitu: datang, bayar, key-in data, tes, dan langsung memperoleh hasil tes (diterima atau ditolak.

Namun demikian, pengembangan ini bukan tanpa persoalan dan kendala. Persoalan pertama adalah investasi yang 
harus dilakukan secara terus menerus dan selalu meningkat setiap tahunnya. Meskipun demikian kendala terbesar yang dihadapi dalam upaya mengembangkan potensi ruang digital justru di aspek kebijakan dan sumber daya manusia. Secara sadar ataupun tidak, manajemen, administrasi dan pengajaran dalam banyak hal masih belum - berjalan optimal (business as usual). Hal ini karena proses mengintegrasikan infrastruktur digital ke dalam infrastruktur dan birokrasi yang ada bukanlah proses yang mudah. Ini adalah proses yang membutuhkan pelatihan, komitmen, waktu dan biaya yang tidak sedikit, sosialisasi dan familiarisasi serta kontinyuitas dan evaluasinya yang juga terus menerus.

Tantangan terbesar yang saat ini juga tengah dihadapi oleh Ull adalah pada upaya integrasi antar sistem informasi dan dengan proses-proses administratif, akademik dan pelayanan-pelayanan lainnya. Pengembangan e-learning misalnya harus diintegrasikan dengan Sistem Informasi Akademik, dengan Sistem Informasi Sumber Daya Manusia, dan dengan Sistem Informasi Keuangan agar memungkinkan otomasi dan manajemen tanpa kertas dapat tercipta. Training-training sedang dilakukan baik didukung oleh dana internal maupun dengan dana hibah (Hibah PHK dan TPSDP).

Langkah keempat yang menjadi bukti komitmen UII untuk meningkatkan daya saing adalah optimalisasi networking, dengan alumni sebagai salah satu basis utamanya. UII berusaha untuk selalu memposisikan diri selangkah lebih maju dibandingkan perguruan tinggi lain dengan mengembangkan kerja sama dengan institusi di dalam dan di luar negeri, dengan lembaga pemerintah dan dengan kalangan industri. Untuk mewujudkan hal tersebut maka banyak dilakukan MoU (Memorandum of Understanding) yang kemudian diimplementasikan pada kegiatan-kegiatan nyata yang telah banyak dilakukan.

Setelah kerja sama dengan universitas di luar negeri berjalan, seperti dengan The University of Wollongong, Monash University dan Pai Chai University, juga telah disepakati kerja sama dengan Dromana and Mornington Secondary Colleges untuk melakukan field study bagi mahasiswa D3 Bahasa Inggris dan IIUM, Malaysia dalam rangka pertukaran staf pengajar, mahasiswa dan bahan ajar. Di samping perguruan tinggi di luar negeri, pengembangan kerja sama dengan perguruan tinggi di dalam negerj juga terus dilakukan, terutama adalah dalam rangka penelitian, pengembangan SDM dan implementasi Sistem Manajemen Mutu. Kerja sama dengan perguruan tinggi dalam negeri yang dilakukan baru-baru ini adalah dengan Universitas Gadjah Mada, Universitas Wijaya Kusuma, dan ISID Gontor. Selain itu UII juga telah melakukan kerja sama dengan beberapa perguruan tinggi negeri dan swasta di Daerah Istimewa Yogyakarta untuk pengembangan perpustakaan.

Untuk lebih memperkokoh posisi UII dalam kancah daerah maupun nasional, kerjasama dengan lembaga pemerintah juga banyak dilakukan, diantaranya adalah kerja samá dengan Mahkamah Agung RI tentang penyelenggaraan pelatihan sengketa ekonomi syariah di peradilan agama, kerja sama dengan Dewan Perwakilan Daerah RI mengenai penyelenggaraan kegiatan akademik dan program-program yang relevan untuk pemberdayaan peran dan fungsi $D P D$ RI. Untuk lebih mendukung upaya pemerintah dalam pemberantasan korupsi, UII juga menjalin kerja sama dengan Komisi Pemberantasan Korupsi (KPK), sehingga hal ini merupakan bentuk tanggung jawab moral UII dalam ikut menyelesaikan persoalan bangsa ini. Kerja sama juga 
terjalin dengan Departemen Pendidikan Nasional RI, yaitu penunjukkan UII sebagai Tim Pemantau Independen tingkat Kabupaten Sleman pada pelaksanaan ujian nasional SMP dan SMA.

UII memandang bahwa keterlibatan stakeholders dálam rangka penyiapan lulusan untuk memasuki dunia sangatlah penting. Hal tersebut diwujudkan dalam jalinan kerjasama dengan kalangan industri, terutama mengenai pelatihan, recruiting lulusan UII, pemberian beasiswa, dan seminar bersama. Kerja sama pelatihan antara lain dilakukan dengan Delcam Plc, Autodesk dan LG Innotek. Untuk memudahkan dan mempercepat lulusan dalam memperoleh pekerjaan Ull dengan koordinasi Alumni Career Centre juga telah mengadakan recruitment on campus yang antara lain dilakukan oleh PT Unilever Indonesia Tbk., PT. Bakrie Sumatera Plantations, PT Pervetti Van Melle, dan PT. Bank Bukopin Tbk.

Pemberian beasiswa telah dilakukan oleh PT Toyota Astra, PT Newmont Nusa Tenggara, dan PT Freeport Indonesia. Beberapa kegiatan seminar.juga dilakukan bersama antara UII dengan beberapa perusahaan maupun asosiasi profesi. Hal ini dilakukan dalam rangka pembekalan bagi calon lulusan untuk dapat menembus dunia kerja. Kegiatan ini menghadirkan Human Resources Development Manager dari berbagai perusahaan, antara lain dari.PT. LG Innotek dan PT Unilever Indonesia Tbk. Sebagaimana disebutkan di atas, salah satu faktor penting dalam membentuk daya saing adalah desain kurikulum yang mampu meningkatkan soft skill alumni agar masa tunggu memperoleh pekerjaan menjadi semakin cepat. Bagi UII upaya ini dilakukan antara lain dengan terus memantau dan mengevaluasi masa tunggu alumni. Masa tunggu alumni bahkan juga menjadi salah satu jaminan mutu yang diukur setiap tahun untuk kemudian dijadikan bahan acuan kebijakan pengembangan alumni.

Pengalaman UII ini sengaja disampaikan untuk menunjukkan beberapa usaha yang terus menerus dilakukan dalam meningkatkan kualitas pengelolaan pendidikan tinggi demi mencapai standar mutu yang selanjutnya meningkatkan daya saing institusi. Namun demikian harus diakui bahwa segala upaya yang telah dilakukan tidak atau belum semuanya mencapai hasil maksimal. Masih banyak kelemahan yang terus-menerus akan menjadi bahan evaluasi dan perbaikan di masa mendatang. Karena bagaimanapun upaya meningkatkan daya saing harus dipahami sebagai bagian dari proses menjaga eksistensi dan keberlangsungan organisasi, sehingga berbagai upaya yang dilakukan akan senantiasa ditingkatkan mengikuti kebutuhan dan tantangan masa depan.

\section{Penutup}

Paparan di atas menunjukkan bahwa upaya membangun daya saing bagi sebuah institusi pendidikan merupakan hal mutlak yảng harus dilakukan demi menjaga eksistensi dan meraih keunggulan di era kompetisi dan globalisasi yang terus merambah dunia pendidikan ini. Salah satu pilihan strategis dalam membangun daya saing tersebut adalah dengan mengambil satu kompetensi dasar yang dimiliki oleh institusi pendidikan untuk kemudian dijadikan entry point pokok bagi peningkatan daya saing tersebut. Dalam rangka meningkatkan daya saing ini, tentu saja banyak kendala dan tantangan yang akan dihadapi manajemen, mulai dari kendala anggaran, kendala organisasi, hingga kendala sumber daya manusia yang akan berkaitan erat dengan komitmen pimpinan, staf, dan seluruh stakeholders membangun daya 
saing dalam institusi pendidikan. Pengalaman yang ditunjukkan pada paparan di atas membuktikan bahwa insitusi pendidikan Indonesia, secara khusus perguruan tinggi, pada dasarnya juga mampu untuk membangun daya saing di bidang pendidikan. Ini semua tentu saja diraih dengan kerjasama dan modal yang tidak sedikit, disertai komitmen yang kuat dari segenap stakeholders pendidikan.

\section{Daftar Pustaka}

Bamey, J., 1991, 'Firm Resources and Sustained Competitive Advantage', Journal of Management, 17(1), 99-120.

Birmingham, R., Hall, S., dan kattan, R., 1997, Shipyard Technology Development Strategies, Joumal of Ship Production, 13(4), 290-300.

Chatterjee, S. dan Wernerfelt, B., 1991, The Link Between Resources and Type of Diversification: Theory and Evidence'. Strategic Management Journal, 12 (1), 33-48.

Chou, C., dan Chang, P. 2004, 'Core Competence and Competitive Strategy of the Taiwan Shipbuilding Industry: a Resource-Based Approach' Maritim Policy Management, ApritJune 2004 Vol. 31, NO. 2, 125-137.

Collis, D.J., 1991, AResource-Based Analysis of Global Competition: The Case of Bearing Industry', Strategic Management Journal, 12, Summer, 4968.

Indrajit, R.E. dan Djokopranoto, R., 2006, Manajemen Perguruan Tinggi Modern, Yogyakarta: PenerbitAndi.
Fernandez, E., Montes, J.M., dan Vazquez, C., 2000, 'Typology And Strategies Analysis of Intangible Resources: A Resource-Based Approach'. Technovation, 20(2), 81-92.

Foil, C. M., 2001, 'Revisiting an identitybased view of sustainable competitive advantage', Joumal of Management, 27(6), 691-699.

Holmes, G. Dan Hooper, N., 2000, 'Core Competence and Education', Higher Education, 40:247-258.

Javidan, M., 1998, 'Core Competence: What Does It Mean In Practice?', Long Rang Planning, 31(1), 60-71.

Porter, M. C., 1985, Competitive Advantage (New York: Macmillan Publishing Co., Inc.).

Porter, M. C., 1990, The Competitive Advantage of Nations (New York: Macmillan Publishing Co., Inc.).

Prahalad, C.K. dan Hamel, G., 1990, The Core Competence of The Corporation, Harvard Business Review, 68(3), 7991.

Ulrich, D. dan Lake, D., 1990, Organizational Capability: Competing from the Inside Out, New York: John Wiley \& Sons Publishing.

Ulrich, D. and Lake, D., 1991, 'Organizational Capability: Creating Competitive Advantage'. Academy of Management Executive, 5(1), 77-92.

Storch, R.L., Clark, J. dan Lamb, T., 1995, 'Technology Survey of U.S. Ship 
yards-1994', Joumal of Ship Production, 11 (13), 133-148.

Taatila, Vesa, The Concept of Organizational Competence-A Foundational Analisys, Dissertation Department of Information Technology of University of Jyvaskyla Finland, 2004.
Wright, P.M., Dunford, B.B., dan Snell, S.A., 2001, "Human Resource and The Resource Based View of The Firm', Journal of Management, 27(6), 701721. 